\title{
DEVELOPMENT OF SELECTED CITIES FROM MASOVIAN VOIVODESHIP IN THE ASPECT OF THE URBAN RESILIENCE CONCEPT
}

\author{
Radosław KORNEĆ \\ Siedlce University of Natural Sciences and Humanities, Faculty of Social Science; radoslaw.kornec@uph.edu.pl, \\ ORCID: 0000-0002-5949-0089
}

Purpose: There are many concepts related to effective management of urban centres that have been advanced recently. One is the concept of urban resilience. This allows determining the level of vulnerability and recovery of city economy to occurring events and phenomenon based on analysis of defined indicators.

Design/methodology/approach: The research problem taken up in this article, it concerns the question of how an assessment of urban resilience can be done in an economic context with the use of open-access statistical data. In Polish literature there are some studies concerning the chosen topic, however, they do not relate to the particular subject of research.

Findings: The results are a certain confirmation of studies that were developed for other urban centres. One common conclusion is that the main external disturbance that significantly changed the selected values of the dynamics of resilience and vulnerability, as well as the line of trajectory related to the development of the studied cities, was the financial crisis that was observed during the years 2009-2012. This particularly affected Warsaw.

Originality/value: The urban resilience concept that was applied in the research is a relatively new approached that is used in diagnosing transitions taking place in cities as a result of external socio-economic conditions. It can be also seen as an important construction for formulating urban policy at the level of municipal government, as well as the direction it will take due to different stages of city development.

Keywords: urban resilience, cities, Masovian voivodeship.

Category of the paper: Research paper.

\section{Introduction}

Over the past few decades, a significant growth in the global urbanisation index has come about. During the years 1950-2000, the number of people living in urban centres rose to $40.1 \%$ from $17.6 \%$. In 2007, the populace living in cities for the first time predominated over the rural population. In 2014, the urban community constituted $54 \%$ of the world's population, 
and according to estimates by United Nations, $66 \%$ of the global populace is expected to be living in urban areas (United Nation, 2015).

The progressing process of global urbanisation, although it is a symbol of social evolution, raises a number of challenges and threats associated with intensive energy consumption, overburdened transport networks, water and air pollution, waste management, social inequality and decline in the quality of life. Despite the fact that cities cover around $0.5 \%$ of the Earth's surface, people who live in them generate $70 \%$ of world GDP, consume $60 \%$ of generated energy and produce about $70 \%$ of all the planet's greenhouse gases and the same amount of global wastes. Moreover, almost 850 million people city dwellers live in very poor districts and slums with common lack of sanitation (Schlör, Venghaus, and Hake, 2018). In addition to chronic challenges and threats, urban centres are subject to sudden and unexpected events, such as financial crises, natural disasters, equipment malfunction or terrorist attacks (Zhang, and $\mathrm{Li}, 2018$ ).

In recent years, many articles can be found in the source literature dealing with smart cities, sustainable cities, creative cities and city maturity. All of these concepts refer to improvement of the quality of life in the urban space by means of applying different tools, forces and means. However, there is still a relatively small number of studies in the urban discourse related to vulnerability and resilience of the cities. One of the first Polish researchers who addressed the above mentioned issue is A. Drobniak, who holds forth that the concept of urban resilience aids in understanding the changes taking place in the city structures conditioned by the changing environment (Drobniak, 2013). The analysis of urban resilience can also enable taking appropriate initiatives which support the potential of urban centres, and which will allow preparation for functioning in precarious and unfavourable conditions (Drobniak, and Plac, 2015).

\section{Conception of urban resilience - literature review}

Resilience consists in adjusting and minimising vulnerability. It is the ability of each system to deal with external changes without extensive modifications of its structure, function and identity (Chelleri, 2012). Resilience and endurance are objects of interest in many sciences and scientific fields, however, in applied sciences they are used to describe the stability of materials, as well as their resilience to external shocks. This definition fits well with the stability features of systems recovering from varied disturbances. The same rule is applied in psychology and psychiatry in terms of individual capacity. Herein it is defined as the ability to cope with changes and events during changes in life (Kaplan, 1999). In the 1960s, the concept of resilience was applied in ecology, where it is defined as "the magnitude of disturbances that can be absorbed before changing the system's structure" (Spaans, and Waterhout, 2017). 
Such understanding of the resilience shows that it is not only the time of impact on the system that is important, but also the force of impact. On the basis of the above perspectives, the most important issue is maintaining a sustainable level that allows systems to retain their features while ensuring the absorption of external (and sometimes internal) changes and disturbances (Drobniak, and Plac, 2015). The resilience category in itself is seen as a positive feature that is conducive to sustainable development (Leichenko, 2011).

The concept of resilience has been introduced relatively recently into the sphere of research dealing with problems of city and regional functioning (Drobniak, and Plac, 2015). In response to adapt social and institutional frameworks to environmental threats, planners and policymakers realised that mitigation of the effects of different events is not sufficient itself, therefore they started to advocate a more flexible approach to the concept of resilience in the decision-making process ( $\mathrm{Lu}$, and Stead, 2013). It is worth noticing that the analysed concept of resilience is different depending on cultural conditions. The difference is distinct especially between Anglo-Saxon and European countries. In the United States or in the United Kingdom, attention is paid to sudden incidents such as terrorist attacks $(9 / 11)$, whereas in Europe the challenge for cities resilience is related to gradually evolving environmental issues.

In the initial period of problem analysis, the raised issues involved mainly threats and challenges, such as terrorist attacks, natural disasters and equipment malfunctions. However, there are many inadequacies in terms of understanding city resilience, and finding one universal definition is extremely difficult even when it comes to one specified science or field (Tab. 1).

Table 1.

Definitions of urban resilience

\begin{tabular}{|l|l|}
\hline Author & Definition \\
\hline Alberti et al. (2003) & $\begin{array}{l}\text { The degree to which cities tolerate alteration before reorganizing around a new } \\
\text { set of structures and processes. }\end{array}$ \\
\hline Pickett et al. (2004) & The ability of a system to adjust in the face of changing conditions. \\
\hline Ernstson et al. (2010) & $\begin{array}{l}\text { To sustain a certain dynamic regime, urban governance also needs to build } \\
\text { transformative capacity to face uncertainty and change. }\end{array}$ \\
\hline Wamsler et al. (2013) & $\begin{array}{l}\text { A disaster resilient city can be understood as a city that has managed... to: } \\
\text { (a) reduce or avoid current and future hazards; (b) reduce current and future } \\
\text { susceptibility to hazards; (c) establish functioning mechanisms and structures } \\
\text { for disaster response; and (d) establish functioning mechanisms and structures } \\
\text { for disaster recovery. }\end{array}$ \\
\hline Desuoza and Flanery (2013) & Ability to absorb, adapt and respond to changes in urban systems. \\
\hline $\begin{array}{l}\text { Smart Mature Resilience, } \\
\text { 2016. Revised Resilience } \\
\text { Maturity Mode Report }\end{array}$ & $\begin{array}{l}\text { Is the ability of a CITY or region to resist, absorb, adapt to and recover from } \\
\text { acute shocks and chronic stressed to keep critical services functioning, and to } \\
\text { monitor and learn from on-going processes through city and cross-regional } \\
\text { collaboration, to increase adaptive abilities and strengthen preparedness by } \\
\text { anticipating and appropriately responding to future challenges. }\end{array}$ \\
\hline $\begin{array}{l}\text { Romero- Lankao and Gnatz } \\
\text { (2013) }\end{array}$ & $\begin{array}{l}\text { A capacity of urban populations and systems to endure a wide array of hazards } \\
\text { and stresses. }\end{array}$ \\
\hline
\end{tabular}

Some researchers question the conception of urban resilience, arguing that resilience is just another phrase that does not contribute any new value (Slater 2014). In turn, Meerow, Newell and Stults think that the analysis of definition and publications on this conception confirm some 
sort of inconsistency and indirectness in the notion of urban resilience (Meerow, Newell, and Stults, 2016). Bearing in mind the challenges connected with clear identification and characteristics of urban resilience, as well as the number of fields and sciences involved in researching this issue, it is not surprising that there are still numerous conceptual and definitional tensions (DaSilva, Kernaghan, and Luque, 2012).

Furthermore, resilience is placed alongside adaptability in the literature (Ahern, Cilliers, and Niemela, 2014). This particularly applies to threats related to climate changes. In the work of Klein et al. there are arguments put forward indicating the precedence of the term adaptation over resilience. It is worth mentioning that in the case of climate changes, formulating so-called 'adaptation strategies for the cities' is becoming more popular (Klein, Nicholls, and Thomalla, 2003). This supports the claim of dominance of the term adaptation. In contrast, certain associations utilize the term 'resilience' in their names, i.e. 'Asian Cities Climate Change Resilience Network (ACCCRN)'. There are also cases where both terms are used together, e.g. the 'Global Forum on Urban Resistance and Adaptation'. As a result, it is difficult to diversify the meaning of both concepts (Bilska, 2016).

The aforementioned considerations confirm the lack of a single definition for the term 'urban resilience' and its many similarities to terms that have been in use for years. For the purpose of this article, the following definition of urban resilience is proposed: it is the ability of the urban system and its socio-ecological and sociotechnical networks in time and space to maintain or quickly return to desirable shape in the face of challenges and threats, and whether it is possible to develop the abilities that guarantee faster development and greater prosperity in urban centres.

Despite many problems resulting from the lack of clear understanding of urban resilience, it may seem that this conception has already inserted itself not only into the research on urban development, but it also constitutes an important category of urban policy.

Propagating the idea of the 'resistant city' is being dealt with today by, among others, the Rockefeller Foundation (an American foundation), which initiated a comprehensive international programme called '100 Resilient Cities' in December 2013. This network is also a think tank - a platform of cooperation between urban theorists and practitioners working on the development of critical reflection and urban 'resistance' (magazynmiasta.pl/miasta podwyższonego ryzyka, 2018). European organisations also engage in the issues of urban development. Within the programme 'Horizon 2020', European-based research centres and municipal authorities have enacted a project called 'Smart Mature Resilience for more resilient cities in Europe', which aims to provide guidelines on resilience management, and to support urban policymakers in developing and implementing resilient tools in their cities (http://www.smr-project.eu/in-memory-of-sarri/, 2018).

As part of the urban resilience concept, the researches on urban resilience and vulnerability use the assumption based on systemic approach. Herein, the term 'city' is recognised as a congeneric and multidimensional system (Drobniak, 2015). Assumptions connected with such 
perception of urban centres with their attributes of resilience and vulnerability are cognitively interesting when it comes to developing methods of assessing urban resilience. On the one hand, they refer to the holistic view of a city (as a complex system), and, on the other hand, the abovementioned assumption facilitates the distribution of the urban system to be a set of attributes.

Urban resilience as a multidimensional and congeneric system may, therefore, depend on a combination of different attributes, for example: collaboration, diversity, efficiency, adaptability, redundancy or interdependence. When these attributes are sufficiently high, they have a positive impact on the level of urban resilience in an economic dimension and they also describe the city's resistance to external turbulences. In turn, the attributes of urban vulnerability are described by features that are contrary to the qualities of urban resilience, including: fragmentation, inadaptability, over-specialisation, insufficiency, discordance or inefficiency. A high value of city vulnerability determines its high exposure to unfavourable phenomena generated by its (economical) surroundings, which results in negative changes in the economic structure of the city. Urban economic resilience can be associated with the ability of urban centres to deal with socio-economic problems in a manner that enables them to achieve a desired level of development (Konecka-Szydłowska, 2018).

\section{City characteristics}

The administrative reform introduced in Poland on 1st January 1999 had a comprehensive nature. Its determinant included four basic aspects: political, structural, functional and territorial (Kaczmarek, 2001). The territorial aspect was very important and it concerned the maintenance of division into communes at local level and restoration of units from voivodeship level over a 25 year period. Changes at regional level regarded correction of boarders and the reduction of the number of voivodeships from 49 to 16 (Chojnicki, and Czyż, 2000). A significant element of the administrative reform was the issue of residences of newly created territorial units, that is poviats (counties), especially cities with poviat rights (magistrate districts). The status of this particular kind of territorial unit is allocated to units that had more than 100000 inhabitants on 31 December 1998, as well as to cities that had ceased begin residences of voivodes on that day, unless at the request of a proper city council, the poviat rights were abandoned. Cities that were given poviat rights at the time of the first administrative division of the country into poviats (Act on Poviat Self-Government, 1998) are also entitled to the aforementioned status. Colloquially, these cities are called 'magistrate districts', and this term is commonly used, however, it should be emphasized that this fact does not result from the regulations of the law. Cities with poviat rights, in practice, are municipalities that have an extended catalogue of assignments (Czupich, 2016). 
Since 2013, 66 urban districts with poviat rights have come into being, including the 10 largest cities with more than 300000 residents (Warszawa, Kraków, Łódź, Poznań, Wrocław, Katowice, Lublin, Bydgoszcz and Szczecin). In the Masovian voivodeship, there are four cities with poviats rights, apart from the aforementioned Warsaw (Warszawa). These cities are the former voivodeship cities, i.e. Radom, Siedlce, Ostrołęka and Płock. In view of the size and the spider-like central character of Warsaw, it has the most important role not only in Masovian Voivodeship, but also in the whole Poland. Therefore it affects the functioning of other urban centres in the voivodeship. The demographic analysis of magistrate districts allows us to state that such cities as Radom, Płock and Ostrołęka have undergone the process of population decline. In the case of Radom and Płock, that process is a result of a natural population drop, but also of a negative net migration rate. According to the population type of classification by J.W. Webb (1964), these cities represented two demographic types: G (Radom, Płock) and H (Ostrołęka) (Tab. 2).

Table 2.

Basic characteristics of the analyzed cities

\begin{tabular}{|l|l|l|l|l|}
\hline City & $\begin{array}{l}\text { Population } \\
\text { in 2017 }\end{array}$ & $\begin{array}{l}\text { Population } \\
\text { dynamics 2005-2017 }\end{array}$ & $\begin{array}{l}\text { Population type } \\
\text { according to } \\
\text { Webb 2015-2017 }\end{array}$ & Type of the city \\
\hline Radom & 214566 & $-5.5 \%$ & $\mathrm{G}$ & $\mathrm{U}$ \\
\hline Siedlce & 77683 & $0.8 \%$ & $\mathrm{~A}$ & $\mathrm{U}$ \\
\hline Ostrolęka & 52215 & $-3 \%$ & $\mathrm{H}$ & $\mathrm{U}$ \\
\hline Płock & 120787 & $-5,2 \%$ & $\mathrm{G}$ & $\mathrm{UP}$ \\
\hline Warszawa & 1764615 & $3,94 \%$ & $\mathrm{C}$ & $\mathrm{U}$ \\
\hline
\end{tabular}

In the analysed period, the population of Radom decreased by almost 12.5 thousand, while Płock had over 6.6 thousand of decline and Ostrołęka by over 1.6. However, in Siedlce, the population grew by almost 600 as the result of a relatively high birthrate. Warsaw also noted an increase in the population that totalled over 16 thousand people, due to a huge surge of people taking advantage of job opportunities (Tab. 3).

Table 3.

Birthrate and net migration rate

\begin{tabular}{|l|l|l|l|l|l|l|l|l|}
\hline \multirow{2}{*}{ City } & \multicolumn{3}{|l}{ Birthrate } & \multicolumn{2}{l}{ Net migration rate } & Birthrate & $\begin{array}{l}\text { Net migration } \\
\text { rate }\end{array}$ \\
\cline { 2 - 9 } & $\mathbf{2 0 1 5}$ & $\mathbf{2 0 1 6}$ & $\mathbf{2 0 1 7}$ & $\mathbf{2 0 1 5}$ & $\mathbf{2 0 1 6}$ & $\mathbf{2 0 1 7}$ & $\mathbf{2 0 1 5 - 2 0 1 7}$ & $\mathbf{2 0 1 5 - 2 0 1 7}$ \\
\hline Radom & -1.5 & -1.0 & -1.3 & -3.8 & -3.3 & -3.4 & -3.8 & -10.5 \\
\hline Siedlce & 3.1 & 3.4 & 3.7 & -1.3 & -0.4 & 0.8 & 10.2 & -0.9 \\
\hline Ostrołęka & 3.1 & 1.6 & 3.0 & -5.8 & -6.5 & -4.5 & 7.7 & -16.8 \\
\hline Plock & -0.9 & -0.8 & -1.2 & -4.1 & -2.9 & -2.9 & -2.9 & -9.9 \\
\hline Warszawa & 0.8 & 1.4 & 1.2 & 4.7 & 4.4 & 4.5 & 3.4 & 13.6 \\
\hline
\end{tabular}

In compliance with nationwide tendencies, the cities with poviat rights in Masovian Voivodeship have undergone a progressive process of dematerialisation of the economy that consists in development of the service sector with the simultaneous decay of the agricultural 
and industrial sectors (Konecka-Szydłowska, and Maćkowiak, 2016). Płock is an exception here, as it is featured by having a strong service-industrial economic structure thanks to PKN Orlen functioning within its borders. The rest of the cities are definitely characterised by a services-oriented profile. The share of workers in the service sector is very similar in Radom, Siedlce and Ostrołęka and it accounts for $63-67 \%$ of the total. Płock as a city of mixed economic structure has approx. $60 \%$ of its people working in the service sector, while people working in the industry sector constitute about $37 \%$. In the presented comparison, the leading city is Warsaw, which as a global centre, distinguishes itself from other cities by having an economy with specific service properties, the share of people working in this sector accounting for $87 \%$ of all the employed.

\section{Methods}

The problem taken up in this article is not a new issue - it concerns the question of how an assessment of urban resilience can be done in an economic context with the use of openaccess statistical data. In Polish literature there are some studies concerning the chosen topic (Drobniak, and Plac, 2015) (Konecka-Szydłowska, 2018), however, they do not relate to the particular subject of research. Taking into account the availability of data provided by the Central Statistical Office, and developed methodology (Drobniak, 2015), several economic indicators were selected which later on facilitated the determination of urban resilience and economic vulnerability of the cities with poviat rights in Masovian Voivodeship. Accordingly, the resilience of the cities in economic dimension was described with indicators that are divided into following groups (attributes):

- adaptability - indicator of the dynamics of the number of economic entities per 1000 of residents and the rate of dynamics of the number of natural persons running an enterprise per 1000 of inhabitants,

- redundancy - indicator of the dynamics of the number of people of productive age per 1000 of residents.

In order to determine vulnerability of the cities in an economic dimension, two indicators assigned to a common attribute were used: incongruity (low level of entrepreneurship factor) dynamics of demographic old-age dependency and dynamics of the share of unemployed people in the total working-age population. 


\section{Results}

In the field of urban resilience, analysed with the use of dynamics of the number of natural persons running enterprises, Warsaw shows much higher value in relation to other cities. Beyond the capital, positive dynamics of this rate were seen only in Siedlce. In the relevant data, the abovementioned rate gradually increased in the analysed period for both cities till 2010, when it reached 111 for both Warsaw and Siedlce. However, a downturn related to the dynamics of the increase in the number of people running enterprises was indicated in 2011 after the global financial crisis. At that time the rate for Siedlce was close to the same indicator from 2005, and in the case of Warsaw it was 6 points lower in comparison to 2010. The other cities in Masovia - Płock, Radom and Ostrołęka, evidenced a relatively constant negative value of the rate (fig. 1).

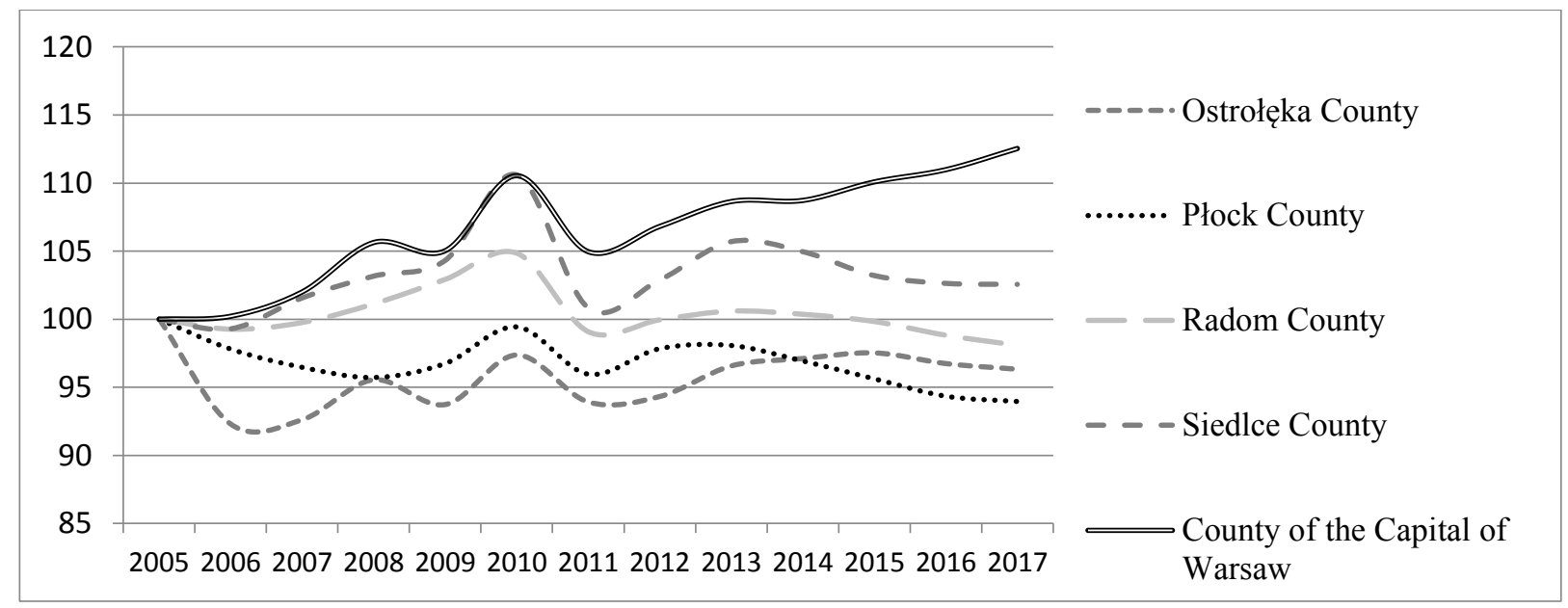

Figure 1. Dynamics of the number of business entities run by natural persons per 1000 people.

While analysing the dynamics of the number of entities entered into the register, relatively similar tendencies can be observed as in the case of dynamics of the number of business entities run by natural persons. The capital of Poland also shows here a significantly higher value in comparison to the other Masovian cities. Despite a clearly upward trend, a particularly high dynamics of the growth was observed in 2011-2017 when the value of the indicator increased from the level of 114 to 140 (during the years 2005-2010, the value of the indicator increased by 15 points). In the other cities of interest, the dynamics are insignificant despite their positive value. It should also be noted that in the case of the other four Masovian cities there are particularly visible fluctuations in the initial period of analysis. Moreover, in the case of Ostrołęka and Płock, the initial period of analysis was characterised by a decrease in index of the number of entities entered into register. 


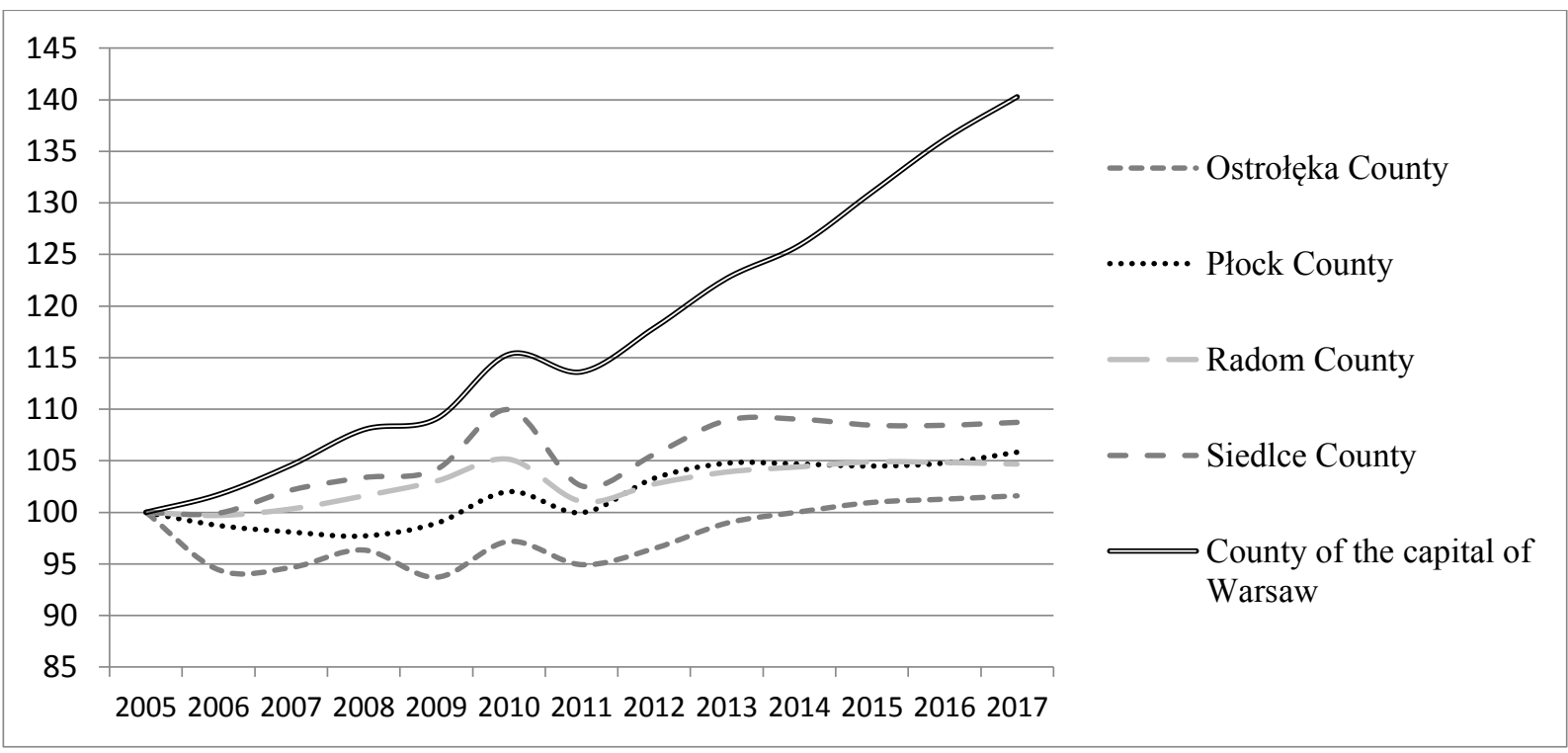

Figure 1. The number of entities entered into register per 1000 people.

The indicator of the number of people of working age useful in describing the urban resilience stability of the analysed cities has been steadily declining in each case - and the values are very similar to each other. In the case of Radom alone, regardless of having the largest outflow of population, this indicator exceeds 90, whereas it is lower for other cities. This decreasing trend does not apply only to the analysed cities of Masovian Voivodeship (Fig 3.). According to the research conducted by B. Konecka-Szydłowska, the small poviat cities in Greater Poland Voivodeship have seen a decline of dynamic indexes at this rate (Konecka-Szydłowska, 2018).

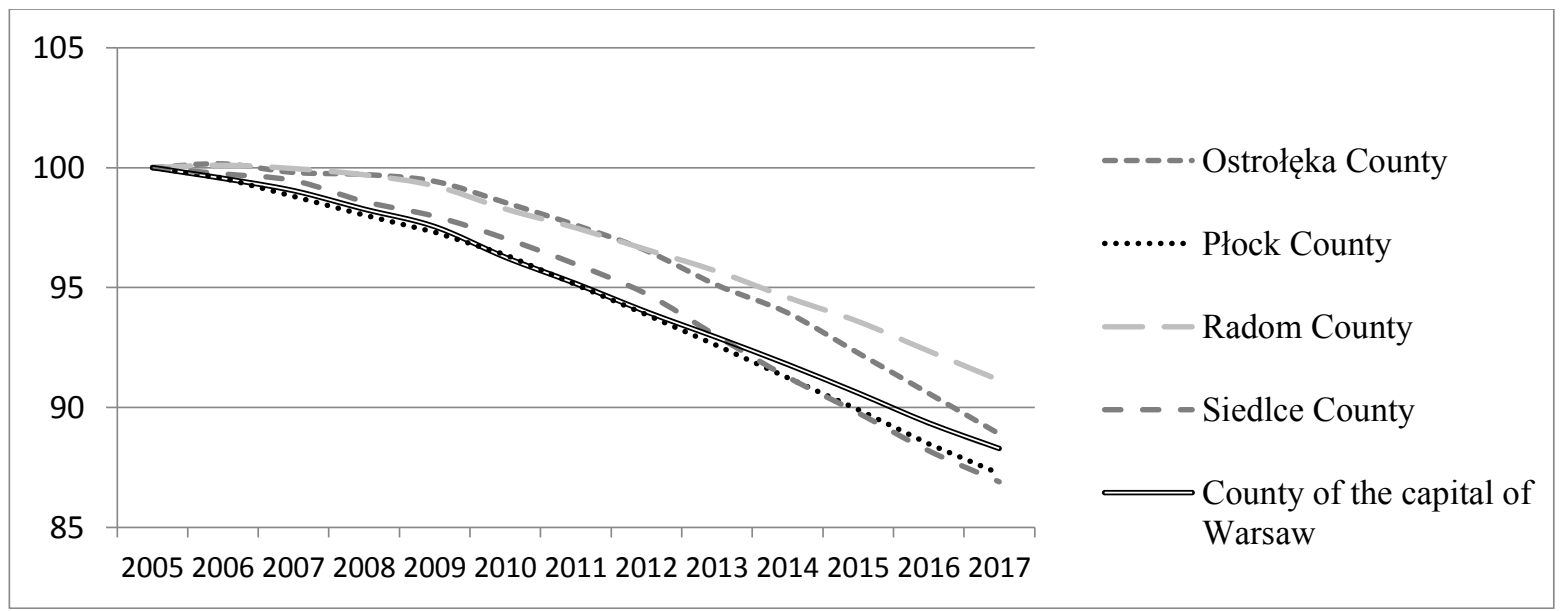

Figure 3. The number of people of working age per 1000 people. 
The first studied rate of economic vulnerability is connected with the dynamics of the number of people of non-productive age per 1000 people of working age. The dynamics of this indicator for individual cities shows a high degree of similarity. Indeed, all cities assessed within this study have shown an upward tendency in the number of people of non-productive age in relation to people of working age. The worst results were observed in Płock (140), Siedlce (139) and Warsaw (136). Despite a negative tendency, Ostrołęka and Radom show the best results, the value of the ratio being 130 (Ostrołęka) and 122 (Radom) (Fig. 3).

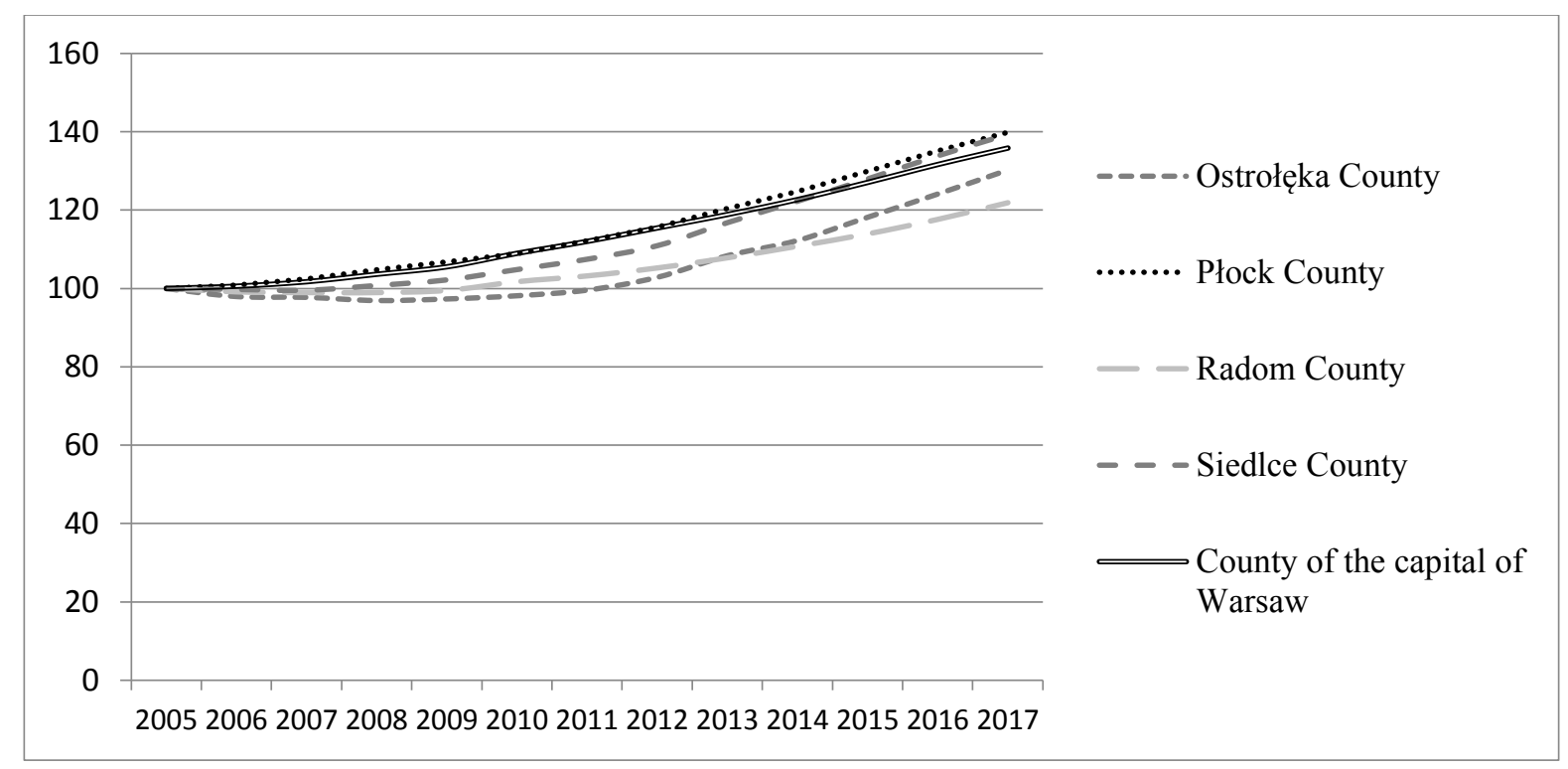

Figure 3. Populace in the non productive age per 1000 people in working age.

Another indicator of vulnerability is the share of unemployed as compared to the number of working age people. The dynamics of this rate shows different scales of change for Warsaw and other cities with poviat rights in Masovian Voivodeship. In the initial stage of analysis, there was a significant decrease in the share of unemployed per total number of people of productive age. This tendency lasted to 2008, when the index evidently decreased to 20 in relation to the base year. However, during the subsequent years, the share of unemployed increased and in 2013, it reached the level of 2005. During 2013-2017, the index decreased again and its value in 2017 was 40 in relation to the base year. The dynamics of change in the share of unemployed per total number of people of productive age for Siedlce, Ostrołęka, Płock and Radom did not fluctuate so much, however, it shows similar relationships. This was mainly a consequence of the financial crisis, which had a lesser influence on the capital of Poland (Fig. 4). 


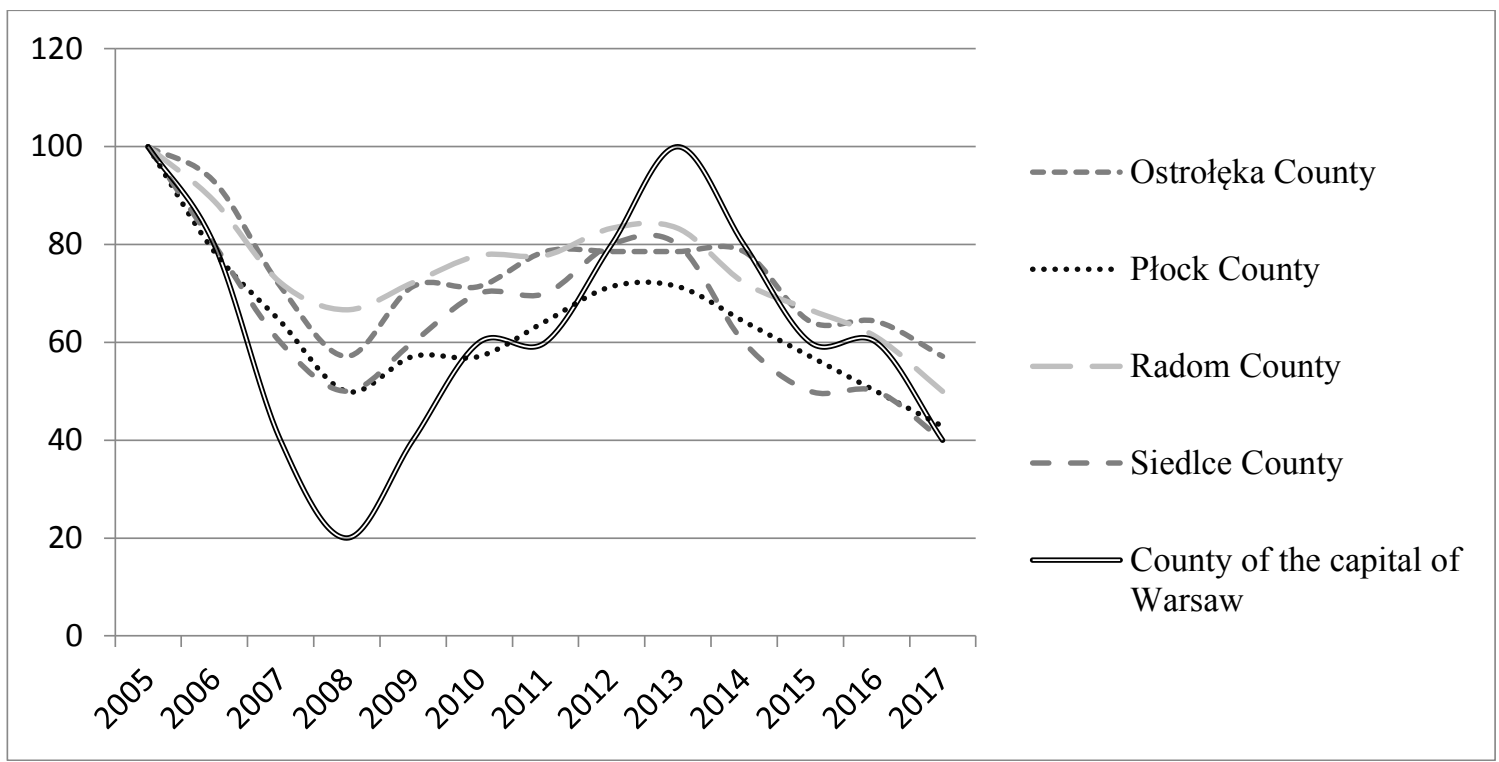

Figure 2. The number of unemployed per 1000 people of productive age.

While calculating average values for indicators of economic urban resilience (variable $\mathrm{x}$ ), as well as average values for vulnerability indicators (variable y), it is possible to capture longterm trajectory of resilience for individual cities (Drobniak, 2015).

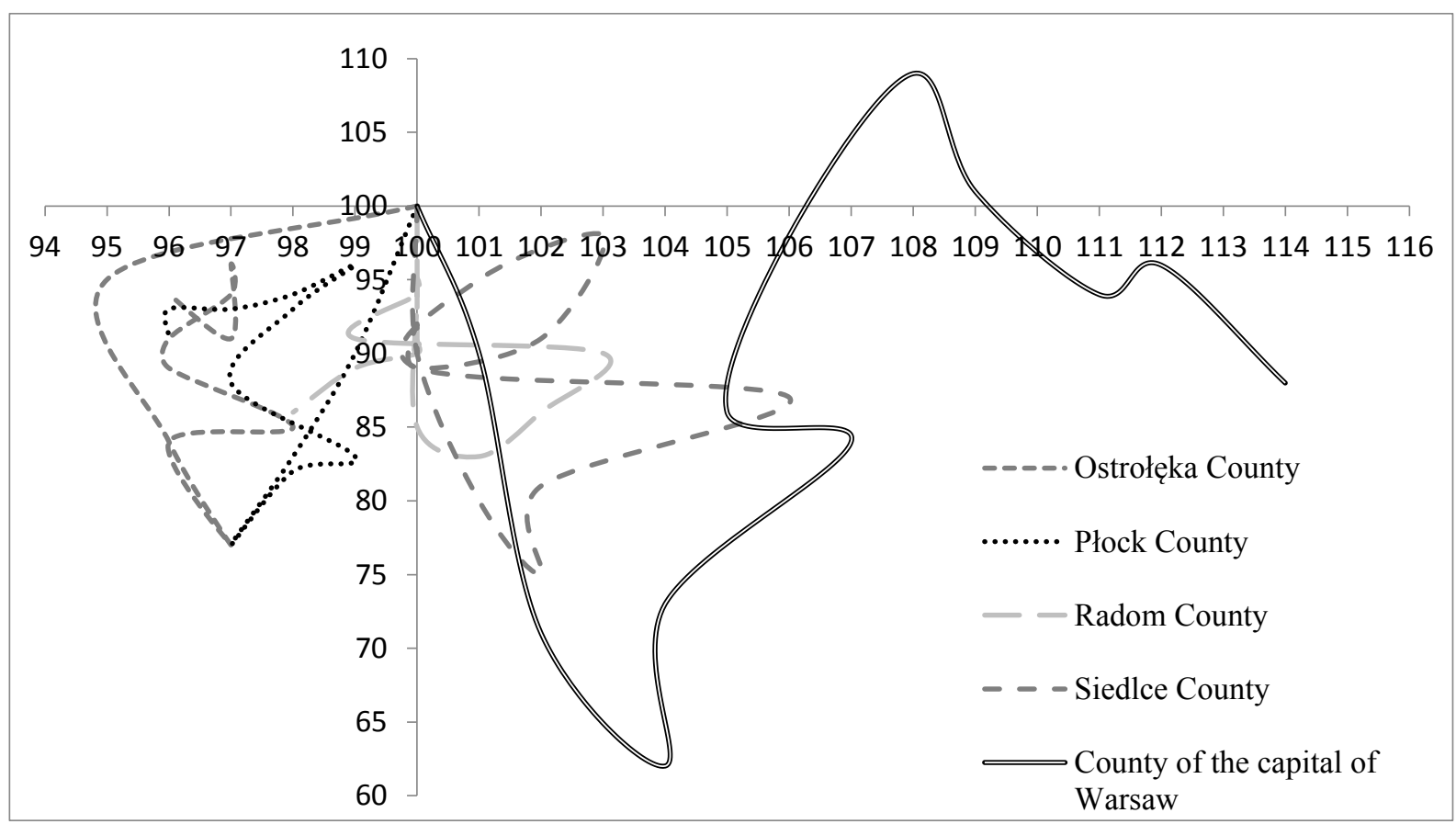

Figure 5. Trajectory of resilience for individual cities.

The analysis of the urban resilience and vulnerability of the cities with poviat rights in Masovian voivodeship in the economic dimension allows us to conclude that poviat centres adapt to contemporary social and economic transformations to varying degrees. A synthetic image of diversity is reflected in different trajectories of their development. Due to important socio-economic role of Warsaw in Europe, it distinguishes itself from other cities in a very clear way. On the one hand, the capital is noted for having a high value of resilience, on the other 
hand, the financial crisis of 2008 has shown how strongly international turbulences have influence on Warsaw's economic condition. Another centre that also has relatively good indicators of resilience is Siedlce. The trajectory for the other three cities shows their weakening of resilience, albeit with simultaneous and gradual improvement of vulnerability (Fig. 5).

\section{Summary}

The urban resilience concept that was applied in the research is a relatively new approached that is used in diagnosing transitions taking place in cities as a result of external socio-economic conditions. It can be also seen as an important construction for formulating urban policy at the level of municipal government, as well as the direction it will take due to different stages of city development. The results are a certain confirmation of studies that were developed for other urban centres. One common conclusion is that the main external disturbance that significantly changed the selected values of the dynamics of resilience and vulnerability, as well as the line of trajectory related to the development of the studied cities, was the financial crisis that was observed during the years 2009-2012. This particularly affected Warsaw. The only one city, which has a positive index of resilience is Siedlce.

\section{References}

1. Ahern, J., Cilliers, S., Niemela, J. (2014). The concept of ecosystem services in adaptive urban planning and design: A framework for supporting innovation. Landscape and Urban Planning, 125, 254-259. Doi: https://doi.org/10.1016/j.landurbplan.2014.01.020.

2. Alberti, M., Marzluff, J.M., Shulenberger, E., Bradley, G., Ryan, C., Zumbrunnen, C. (2003). Integrating humans into ecology. Opportunities and challenges for studying urban ecosystems. BioScience, 53(12), 1170. doi: https://doi.org/10.1641/0006-3568(2003) 053[1169:IHIEOA]2.0.CO;2.

3. Bilska, A. (2016). Proces budowy miasta odpornego na przykładzie Rotterdamu. Rozwój Regionalny i Polityka Regionalna, 34, 61.

4. Chelleri, L. (2012). From the "Resilient City" to Urban Resilience. A review essay on understanding and integrating the resilience perspective for urban systems. Documents d'Anŕlisi Geogrŕfica, 58, 290. Retrieved from https://www.researchgate.net/publication/ 262817700_From_the_Resilient_City_to_Urban_Resilience_A_review_essay_on_unders tanding_and_integrating_the_resilience_perspective_for_urban_systems, 18.11.2018. 
5. Chojnicki, Z., Czyż, T. (2000). Nowa organizacja terytorialna Polski i układ regionalny. Czasopismo Geograficzne, 3-4, 261-277.

6. Czupich, M. (2016). Sytuacja budżetowa wybranych miast na prawach powiatu. SpaceSociety-Economy, 16, 30.

7. Da Silva, J., Kernaghan, S., Luque, A. (2012). A systems approach to meeting the challenges of urban climate change. International Journal of Urban Sustainable Development, 4(2), 125-145. doi: https://doi.org/10.1080/19463138.2012.718279.

8. Desouza, K.C., Flanery, T.H. (2013). Designing, planning, and managing resilient cities: A conceptual framework. Cities, 35, 89. Doi: https://doi.org/10.1016/j.cities.2013.06.003.

9. Drobniak, A. (2013). Urban resilience - nowa perspektywa badawcza rozwoju miasta. Studia Komitetu Przestrzennego Rozwoju Kraju, 153, 204-221.

10. Drobniak, A. (2015). Koncepcja Urban Resilience: narzędzie strategicznej diagnozy i monitoringu miast. Ruch prawniczy, ekonomiczny i socjologiczny, 1, 123.

11. Drobniak, A., Plac, K. (2015). Urban resilience - studia przypadków oceny ekonomicznej prężności miejskiej. Prace Naukowe Uniwersytetu Ekonomicznego we Wrocławiu, 391, 52.

12. Ernstson, H., van der Leeuw, S.E., Redman, C.L., Meffert, D.J., Davis, G., Alfsen, C., et al. (2010). Urban transitions: On urban resilience and human-dominated ecosystems. Ambio, 39(8), 533. Doi: https://doi.org 10.1007/s13280-010-0081-9.

13. Kaczmarek, T. (2001). Reforma terytorialno-administracyjna Polski - porównanie z krajami Unii Europejskiej. Biuletyn Komitetu Przestrzennego Zagospodarowania Kraju $P A N, 197,131-155$.

14. Kaplan, H.B. (1999). Toward an understanding of resilience: a critical review of definition and models. In: M.D. Glantz, and J.L. Johnson (eds.), Resilience and Development: Positive life adaptation (pp. 17-83). New York: Kluwer Academic/Plenum.

15. Klein, R.J.T., Nicholls, R.J., Thomalla, F. (2003). Resilience to natural hazards: how useful is this concept? Global Environmental Change Part B: Environmental Hazards, (5)1-2, 35-45. doi: https://doi.org/10.1016/j.hazards.2004.02.001.

16. Konecka-Szydłowska, B. (2018). Rozwój małych miast powiatowych województwa wielkopolskiego w ujęciu koncepcji Urban Resilience. Space-Society-Economi, 24, 33.

17. Konecka-Szydłowska, B., Maćkowiak, H. (2016). Zróżnicowanie funkcjonalne miast województwa wielkopolskiego. Rozwój Regionalny i Polityka Regionalna, 36, 39-56.

18. Leichenko, R. (2011). Climate change and urban resilience. Current Opinion in Environmental Sustainability, 3(3), 164-168. doi: https://doi.org/10.1016/j.cosust. 2010.12.014.

19. Lu, P., Stead, D. (2013). Understanding the notion of resilience in spatial planning: A case study of Rotterdam, The Netherlands. Cities, 35, 200-212. doi: https://doi.org/10.1016/ j.cities.2013.06.001. 
20. Meerow, S., Newell, J.P., Stults, M. (2016). Defining urban resilience: A review. Landscape and Urban Planning, 147, 40. doi: https://doi.org/10.1016/j.landurbplan. 2015.11.011.

21. Miasta podwyższonego ryzyka. Retrieved from http://magazynmiasta.pl/2017/09/09/ miasta-podwyzszonego-ryzyka/, 18.11.2018.

22. Pickett, S.T.A., Cadenasso, M.L., Grove, J.M. (2004). Resilient cities: Meaning, models, and metaphor for integrating the ecological, socio-economic, and planning realms. Landscape and Urban Planning, 69(4), 373. doi: https://doi.org/10.1016/j.landurbplan. 2003.10.035.

23. Romero-Lankao, P., Gnatz, D.M. (2013). Exploring urban transformations in Latin America. Current Opinion in Environmental Sustainability, 5(3-4), 358. doi: https://doi.org/10.1016/j.cosust.2013.07.008.

24. Schlör, H., Venghaus, S., Hake, J.F. (2018). The FEW-Nexus city index - Measuring urban resilience. Applied Energy, 210, 382. doi: https://doi.org/10.1016/j.apenergy.2017.02.026.

25. Slater, T. The resilience of neoliberal urbanism. Retrieved from https:/www.opendemocracy.net/opensecurity/tom-slater/resilience-of-neoliberalurbanism, 13.11.2018.

26. Smart Mature Resilience Deliverable 2.5: Requirements of Cities Regarding Resilience. Retrieved from http://smr-project.eu/fileadmin/user_upload/Documents/Resources/WP_2/ D2_5_Resilience_Requirements_Reviewed.pdf, 11.12.2018.

27. Smart Mature Resilience Project. Retrieved from http://www.smr-project.eu/in-memoryof-sarri/, 18.11.2018.

28. Spaans, M., Waterhout, B. (2017). Building up resilience in cities worldwide - Rotterdam as participant in the 100 Resilient Cities Programme. Cities, 61, 109. doi: https://doi.org/ 10.1016/j.cities.2016.05.011.

29. Stangel, M. (2013). Kształtowanie współczesnych obszarów miejskich w kontekście zrównoważonego rozwoju. Gliwice: Politechnika Śląska, 26-27.

30. United Nation (15.12.2017). World Urbanization Prospects. New York. Retrieved from https://esa.un.org/unpd/wup/Publications/Files/WUP2014-Highlights.pdf.

31. Wamsler, C., Brink, E., \& Rivera, C. (2013). Planning for climate change in urban areas: From theory to practice. Journal of Cleaner Production, 50, 71. doi: https://doi.org/ 10.1016/j.jclepro.2012.12.008.

32. Zhang, X., Li, H. (2018). Urban resilience and urban sustainability: What we know and what do not know? Cities, 72, 141. doi: https://doi.org/10.1016/j.cities.2017.08.009. 